\title{
PENGARUH PEMBERIAN EKSTRAK DAUN PLETEKAN (RUELLIA TUBEROSA L.) TERHADAP KADAR GLUKOSA DARAH PADA TIKUS PUTIH (RATTUS NOVERGICUS) STRAIN WISTAR YANG DIINDUKSI ALLOXAN
}

\author{
Rizky Ayundha Sari ${ }^{1}$, Alfa Sylvestris ${ }^{2}$, Moch Bahrudin ${ }^{3}$ \\ Klinik Pratama Bakti Timah
}

\begin{abstract}
ABSTRAK
Pengaruh Pemberian Ekstrak Daun Pletekan (Ruellia Tuberosa L.) Terhadap Kadar Glukosa Darah Pada Tikus Putih (Rattus Novergicus) Strain Wistar Yang Diinduksi Alloxan. Belum banyak diketahui bahwa daun pletekan mengandung senyawa flavonoid yang berkhasiat sebagai antioksidan serta meningkatkan aktifitas insulin sehingga dapat berfungsi sebagai protektor sel $\beta$ pankreas dan mampu menurunkan kadar glukosa darah pada penderita diabetes mellitus. Tujuan : Membuktikan adanya pengaruh pemberian ekstrak daun pletekan (Ruellia tuberosa L.) terhadap kadar glukosa darah pada tikus putih (Rattus novergicus) strain wistar yang diinduksi Alloxan. Metode : True Experimental, dengan rancangan Pre post test Control Desain. Sampel tikus putih strain wistar yang dibagi 4 kelompok. Analisis data menggunakan One way Anova, uji tukey 1\%. Hasil Penelitian dan Diskusi : Dari hasil uji One way Anova, didapatkan pengaruh yang bermakna (nilai sig $\mathrm{p}<0,01$ ) antar kelompok dan perlakuan. Hasil uji tukey 1\%, menunjukkan bahwa terdapat perbedaan yang bermakna antar kelompok perlakuan dalam penelitian, yakni kenaikan dosis ekstrak pletekan mampu melindungi sel $\beta$ pankreas dan menyebabkan penurunan kadar glukosa darah tikus putih. Kesimpulan : Pemberian ekstrak daun pletekan mampu sebagai protektor terhadap sel $\beta$ pancreas dan menurunkan secara signifikan kadar glukosa darah pada tikus puth (Rattus norvegicus) strain wistar yang diinduksi Alloxan.
\end{abstract}

\begin{abstract}
The effect of Pletekan Leaf Extract (Ruellia Tuberosa L.) to Blood Glucose Level on White Mouse (Rattus Novergicus Strain Wistar) Inducted by Alloxan. Little positive effect ever known that pletekan leaves contained flavonoid that can be used as an antioxidant that could increase insulin's activity so that played a role as a protector for pancreatic? cell that could decrease the blood glucose levels in diabetes mellitus models. Objective: To prove that there was an effect of Pletekan leaf extract (Ruellia tuberosa L.) to blood glucose level on white mouse (Rattus novergicus) strain wistar inducted by Alloxan. Method: True Experimental, with Pre post test Control Design. White mouse strain wistar samples were divided into 4 groups. Datas were analyzed using One way Anova and Tukey test 1\%. Result and Discussion: One way Anova test showed that there was meaningful effect (sig p value $<0,01)$ between these groups and those treatments. Tukey test 1\% showed that there were meaningful differences between those groups with different treatments in this study, that increased the Pletekan leaf extract dosages were able to protect? cell of the pancreas and decreasing the blood glucose level. Conlusion: Pletekan leaf extract was able to become as a protector of pancreatic? cell and had proven significantly decreased the blood glucose level in white mouse (Rattus norvegicus) strain wistar inducted by Alloxan.
\end{abstract}

Key words: Pletekan leaf extract, Blood glucose, Antioxidant, Flavonoid.

\section{PENDAHULUAN}

Dewasa ini kebutuhan terhadap obat tradisional terus meningkat. Di negara berkembang konsumsi masyarakat terhadap obat tardisional mencapai $80 \%$ dari jumlah populasinya (Solikin, 2007). Salah satu obat tradisional yang terus dikembangkan kearah fitofarmaka adalah obat antidiabetes (Nugroho, 2002). Salah satu tumbuhan yang berkhasiat menurunkan kadar gula darah, antara lain Brotowali (Tinospora crispa L.), Lidah buaya (Aloe vera L.), Mahoni (Swietenia mahagoni), Salam (Syzygium polyanthum), Sambiloto (Andrographis paniculata), Pletekan (Ruellia tuberosa L.) (Dalimartha, 2005). Namun demikian tumbuhan yang belum banyak diketahui khasiatnya oleh masyarakat adalah Ruellia tuberosa L. yang mudah di dapatkan dan banyak tumbuh di tepi jalan, pematang sawah, atau pada semak-semak. Ruellia tuberosa L. adalah tumbuhan tropis yang tersebar secara luas di Asia Tenggara. Dalam pengobatan tradisional Ruellia tuberosa L. dapat digunakan sebagai diuretik, antidiabetik, antipiretik, analgesik, antihipertensi, dan agen antidotum (Lin et al, 2006).

Diabetes mellitus adalah salah satu penyakit metabolik, yang ditandai dengan meningkatnya glukosa darah. Diabetes mellitus akan meningkat jumlahnya di masa mendatang dan merupakan ancaman utama bagi kesehatan umat manusia di abad 21. Penderita diabetes mellitus di Indonesia pada tahun 2000 mencapai 8,4 juta orang dan 
menduduki peringkat keempat setelah India, Cina, dan Amerika Serikat. Jumlah tersebut diperkirakan akan meningkat lebih dari dua kali lipat pada tahun 2030 yang mencapai 21,3 juta orang (Subroto, 2006). Prevalensi diabetes mellitus secara menyeluruh sekitar $6 \%$ dari populasi, $90 \%$ diantaranya diabetes mellitus tipe 2 . Diabetes mellitus ditandai dengan kadar glukosa darah yang melebihi normal (hiperglikemia) sebagai akibat dari tubuh yang kekurangan insulin relatif maupun absolut. Diabetes Mellitus juga ditandai dengan gejala poliuria, polidipsi, polifagia, penurunan berat badan, dan lemas. Bila gejala-gejala tersebut tidak diobati dan berlangsung lama dapat menyebabkan komplikasi makro dan mikrovaskuler, misalnya atherosclerosis pada jantung, kaki dan otak, kerusakan syaraf perifer, gangguan retina dan kerusakan ginjal (Murray, 2003).

Obat antidiabetes oral berguna untuk penderita yang alergi terhadap insulin atau yang tidak menggunakan suntikan insulin. Penggunaan obat antidiabetes oral harus dipahami oleh penderita diabetes mellitus, agar didapatkan kesesuaian dosis dengan indikasinya tanpa menimbulkan keluhan hipoglikemia. Obat antidiabetes oral kebanyakan memberikan efek samping yang tidak diinginkan antara lain mual, muntah, hipoglikemia, bahkan kerusakan ginjal dan harganya relatif mahal, sehingga para ahli mengembangkan sistem pengobatan tradisional untuk diabetes mellitus yang relatif aman (Studiawan dan Santosa, 2005).

Melihat fenomena diatas, peneliti tertarik untuk meneliti pengaruh pemberian ekstrak daun pletekan (Ruellia tuberosa L.) terhadap kadar glukosa darah pada tikus putih (Rattus norvegicus) strain wistar yang diinduksi Alloxan.

\section{METODE PENELITIAN}

Penelitian ini adalah penelitian True Experimental dengan desain penelitian yang digunakan adalah Pre-Post test control desaign yaitu dilakukan pengamatan/pengukuran kadar glukosa darah sebelum dan sesudah perlakuan. Penelitian ini menggunakan 24 ekor tikus putih (Rattus norvegicus strain wistar), dibagi menjadi 4 kelompok dan masing-masing kelompok terdiri dari 6 ekor tikus. Kelompok I : Kontrol positif (Alloxan tanpa pemberian ekstrak daun Ruellia tuberosa L.), Kelompok II : Pemberian Alloxan dan ekstrak daun Ruellia tuberosa L.0,2781 ml/200gBB/hari, Kelompok III : Pemberian Alloxan dan ekstrak daun Ruellia tuberosa L.0,4171ml $/ 200 \mathrm{gBB} /$ hari, Kelompok IV : Pemberian Alloxan dan ekstrak daun Ruellia tuberosa L.0,5562ml/200gBB/ hari. Penelitian dilakukan di Laboratorium Kimia Universitas Muhammadiyah Malang, pada bulan Februari - Maret 2011.

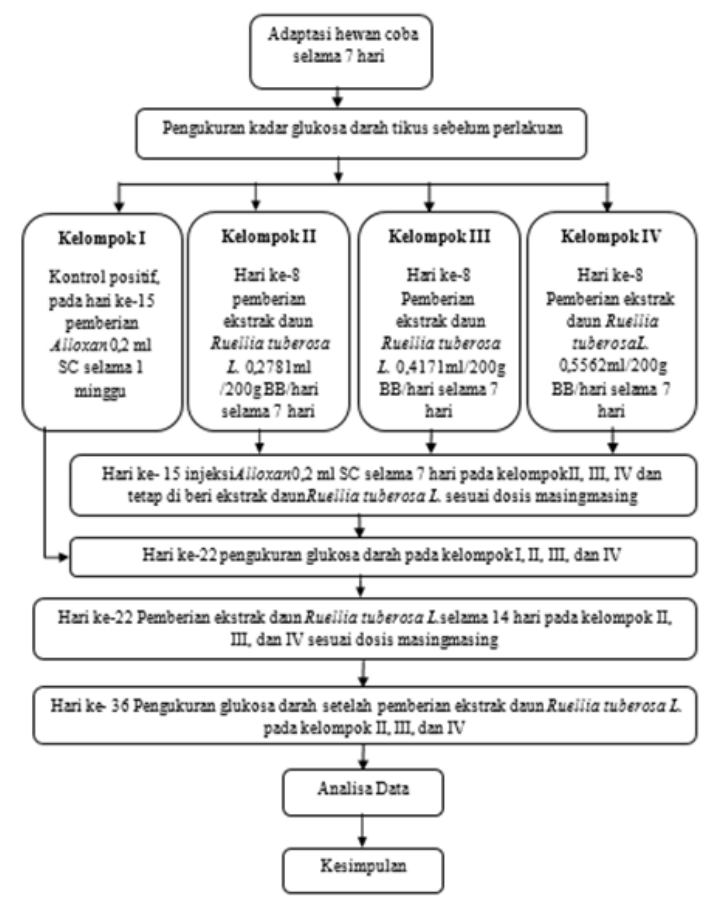

Gambar 1. Alur Penelitian

Analisis statistik yang digunakan adalah One way ANOVA, yaitu untuk menguji hipotesis kesamaan rata-rata antar kelompok ( $>2$ kelompok), apakah rata-rata antar sampel berbeda secara signifikan atau tidak; dengan tingkat kepercayaan $\alpha=0,01$, di mana apabila diperoleh $\alpha>0,01$ artinya tidak ada perbedaan yang bermakna sebaliknya bila $\alpha<0,01$ menunjukkan adanya perbedaan yang bermakna, dan uji Tukey 1\% merupakan uji kelanjutan dari uji ANOVA, digunakan untuk mengetahui perbedaan yang bermakna antar kelompok perlakuan dalam penelitian.

\section{HASIL DAN PEMBAHASAN}

Hasil pengukuran kadar glukosa darah sebelum perlakuan pada hari ke- 8 dan hari ke-22 dapat dilihat pada tabel 1. dan 2.

Tabel 1. Hasil Pengukuran Kadar Glukosa Darah Tikus Sebelum Perlakuan Pada Hari k-8

\begin{tabular}{|c|c|c|c|c|c|c|c|}
\hline \multirow[t]{2}{*}{ Perlakuan } & \multicolumn{6}{|c|}{ Glukosa darah (mg/dl) - Ulangan } & \multirow{2}{*}{ Rerata \pm SD } \\
\hline & 1 & 2 & 3 & 4 & 5 & 6 & \\
\hline I & 114.841 & 113.074 & 112.721 & 110.601 & 107.420 & 116.254 & $112.485 \pm 3.142$ \\
\hline II & 112.014 & 113.781 & 111.661 & 114.488 & 113.074 & 119.788 & $114.134 \pm 2.965$ \\
\hline III & 110.954 & 107.067 & 107.420 & 109.894 & 117.668 & 112.367 & $110.895 \pm 3.893$ \\
\hline IV & 118.728 & 112.721 & 115.548 & 113.781 & 114.841 & 109.187 & $114.134 \pm 3.168$ \\
\hline
\end{tabular}

Tabel 2. Hasil Pengukuran Kadar Glukosa Darah Tikus Pada Hari ke-22

\begin{tabular}{|c|c|c|c|c|c|c|c|}
\hline \multirow{2}{*}{ Perlakuan } & \multicolumn{5}{|c|}{ Glukosa darah (mg dil) - Ulangan } & \multirow{2}{*}{ Rerata=SD } \\
\cline { 2 - 7 } & 1 & 2 & 3 & 4 & 5 & 6 & \\
\hline I & 230.742 & 213.428 & 221.908 & 225.442 & 218.728 & 226.502 & $222.792 \pm 6.148$ \\
\hline II & 180.565 & 178.092 & 163.251 & 171.731 & 155.124 & 174.558 & $170.554 \pm 9.653$ \\
\hline III & 146.996 & 137.102 & 140.636 & 151.590 & 137.102 & 140.636 & $142.344 \pm 5.795$ \\
\hline IV & 124.028 & 123.322 & 129.329 & 131.095 & 137.102 & 139.223 & $130.683 \pm 6.552$ \\
\hline
\end{tabular}


Tabel diatas menunjukkan bahwa glukosa darah sebelum penelitian pada hari ke- 8 secara keseluruhan berkisar 110,895 - 114,134 mg/dl dan relatif homogen, rerata kadar glukosa darah tikus menunjukkan angka normal. Pada hari ke-22 kelompok I (kontrol positif) yang diinduksi dengan Alloxan saja $0,2 \mathrm{ml} /$ ekor/hari selama 7 hari tampak mengalami kenaikan kadar glukosa darah yang meningkat sangat tinggi hingga 222,792 mg/dl. Sedangkan kelompok tikus yang sebelumnya diberi ekstrak pletekan selama 7 hari dengan dosis 0,2781 ml/ekor/hari kemudian diberi Alloxan 0,2 ml/ ekor/hari yang disertai dengan pemberian ekstrak pletekan lagi sesuai dosis selama 7 hari (II), kadar glukosa darahnya naik hingga 170,554 mg/dl dengan rerata 170.554 99.653 . Kelompok tikus yang sebelumnya diberi ekstrak pletekan $0,4171 \mathrm{ml} /$ ekor/hari selam 7 hari kemudian diberi Alloxan disertai dengan pemberian ekstrak pletekan lagi sesuai dosis selama 7 hari (III), kadar glukosa darahnya naik hingga $142,344 \mathrm{mg} / \mathrm{dl}$ dengan rerata $142.344 \pm 5.795$. Kelompok tikus yang sebelumnya diberi ekstrak pletekan $0,5562 \mathrm{ml} /$ ekor/hari selama 7 hari kemudian diberi Alloxan disertai dengan pemberia ekstrak pletekan lagi sesuai dosis selama 7 hari (IV), kadar glukosa darahnya naik hingga 130,683 mg/ dl dengan rerata $130.683 \pm 6.552$. Sehingga didapatkan rerata kenaikan kadar glukosa darah terendah pada kelompok IV.

Pada hari ke-22 setelah pengukuran kadar glukosa darah, kelompok II, III, IV diberi ekstrak daun pletekan lagi sesuai dengan dosis masing-masing kelopok selama 14 hari, kemudian dilakukan pengukuran kadar glukosa darah kembali pada hari ke-36. Hasil pengukran kadar glukosa darah tikus hari ke-36 dapat dilihat pada table 3.

Tabel 3. Data Glukosa Darah Pada Hari Ke-36

\begin{tabular}{|c|c|c|c|c|c|c|c|}
\hline \multirow[t]{2}{*}{\begin{tabular}{|l|} 
Perlakuan \\
\end{tabular}} & \multicolumn{6}{|c|}{ Ulangan } & \multirow[t]{2}{*}{ Rerata + SD } \\
\hline & 1 & 2 & 3 & 4 & 5 & 6 & \\
\hline II & 153.004 & 146.996 & 141.696 & 138.516 & 137.102 & 156.184 & $145.583=7.82$ \\
\hline IIII & 115.194 & 109.894 & 118.021 & 120.848 & 125.442 & 127.562 & $119.494 \pm 6.559$ \\
\hline IV & 120.495 & 117.314 & 115.194 & 109.187 & 113.428 & 119.081 & 115 . \\
\hline
\end{tabular}

Tabel diatas menunjukkan bahwa pada kelompok tikus yang diberi ekstrak daun pletekan $0,2781 \mathrm{ml} /$ ekor/hari (II), kadar glukosa darahnya turun hingga $145,583 \mathrm{mg} / \mathrm{dl}$. Kelompok tikus yang diberi ekstrak daun pletekan 0,4171 $\mathrm{ml} /$ ekor/hari (III), kadar glukosa darahnya turun hingga 119,494 mg/dl. Kelompok tikus yang diberi ekstrak daun pletekan $0,5562 \mathrm{ml} /$ ekor/hari (IV), kadar glukosa darahnya turun hingga mendekati kadar glukosa darah sebelum perlakuan yaitu $115,783 \mathrm{mg} / \mathrm{dl}$.

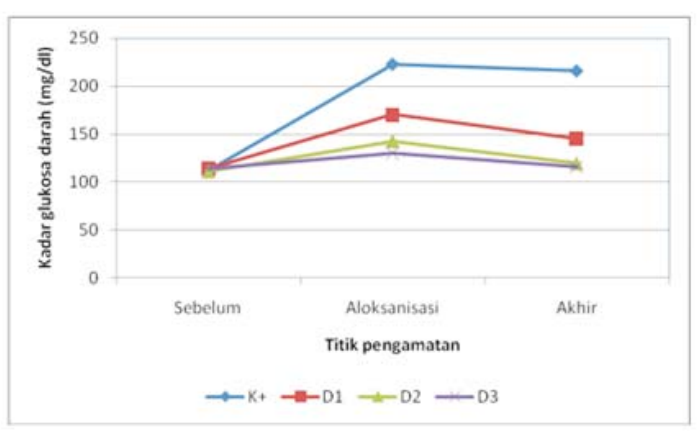

Gambar 2. Hasil Penelitian
Keterangan:

$\mathrm{K}+$ : Kelompok I (Kontrol positif)

D1 : Kelompok II (dosis ekstrak pletekan 0,2781ml/ 200g/BB/hari)

D2 : Kelompok III (dosis ekstrak pletekan 0,4171ml/ 200g/BB/hari)

D3 : Kelompok IV (dosis ekstrak pletekan 0,5562ml/ 200g/BB/hari)

Pemberian Alloxan untuk kelompok I pada hari ke-22 menunjukkan peningkatan kadar glukosa darah yang berkisar $222,792 \mathrm{mg} / \mathrm{dl}$. Kadar glukosa darah tikus sudah meningkat dua kali dari normal. Hal ini sesuai dengan penelitian yang dilakukan oleh Studiawan dan Santosa (2005) "Uji Aktivitas Penurunan Kadar Glukosa Darah Dengan Ekstrak Daun Polyantha pada Tikus yang Diinduksi Aloksan". Pada penelitian Studiawan dan Santosa tersebut menyatakan bahwa semua hewan coba yang diinduksi aloksan selama 1 minggu menunjukkan kenaikan kadar glukosa darah yang bermakna. Peningkatan kadar glukosa darah juga dapat dijelaskan melalui teori yang menyatakan bahwa Alloxan akan menginduksi terjadinya pelepasan radikal bebas berupa oksigen reaktif yang target primernya adalah sel $\beta$ pankreas. Radikal bebas akan menyebabkan kerusakan pada sel $\beta$ pankreas. Alloxan bereaksi dengan merusak substansi esensial di dalam sel $\beta$ pankreas sehingga menyebabkan berkurangnya pembawa insulin di dalam sel $\beta$ pankreas. Alloxan dalam darah berkaitan dengan GLUT 2 yang memfasilitasi masuknya alloxan ke dalam sitoplasma sel $\beta$ pankreas. Di dalam sel $\beta$, alloxan menimbulkan depolarisasi berlebih pada mitokondria sebagai pemakaian ion $\mathrm{Ca} 2+$ yang diikuti dengan penggunaan energy berlebih sehingga terjadi kekurangan energy dalam sel, mekanisme ini mengakibatkan kerusakan baik dalam jumlah sel maupun massa sel pankreas sehingga terjadi penurunan pelepasan insulin. Tingkat kerusakan yang ditimbulkan oleh Alloxan bersifat stabil dan dapat bertahan selama 5 minggu (Mulder, 2002).

Pada kelompok II, III, dan IV setelah di beri ekstrak daun pletekan dan Alloxan didapatkan kadar glukosa darah pada kelompok II naik hingga 170,554 mg/dl, kelompok III kadar glukosa darah naik hingga $142,344 \mathrm{mg} / \mathrm{dl}$, sedangkan pada kelompok IV kadar glukosa darah naik hingga 130,683 mg/dl. Rerata kenaikan kadar glukosa darah terendah pada kelompok IV. Sehingga pemberian dosis ekstrak daun pletekan yang lebih tinggi dapat mencegah tingginya peningkatan kadar glukosa darah tikus putih karena kandungan flavonoid yang ada di dalam ekstrak daun pletekan memiliki efek sebagai antioksidan yang dapat melindungi sel-? pankreas dari kerusakan yang ditimbulkan oleh radikal bebas dari induksi Alloxan. Hasil ini diperkuat oleh teori yang menyatakan bahwa kemampuan Flavonoid sebagai antioksidan mampu menurunkan stress oksidatif, hal ini dapat menimbulkan efek protektif terhadap sel beta pankreas dan meningkatkan sensitivitas insulin (Kaneto et al, 1999).

Pada hari ke-22 kelompok II, III, dan IV diberi ekstrak daun pletekan (Ruellia tuberosa L.) selama 14 hari dengan dosis masing-masing yang bertujuan untuk megetahui apakah ekstrak daun pletekan (Ruellia tuberosa L.) mampu membuat kadar glukosa darah mendekati normal atau seperti kadar glukosa darah tikus sebelum perlakuan. Akhir perlakuan 
(hari ke-36) setelah pemberian ekstrak daun pletekan (Ruellia tuberosa L.) kadar glukosa darah kelompok II, III, IV diukur. Pemberian perlakuan pada hari ke-22 sampai hari ke-36 menunjukkan perubahan kadar glukosa darah yang mendekati normal atau seperti kadar glukosa darah tikus sebelum perlakuan. Hal ini diperkuat oleh teori yang menyatakan bahwa flavonoid menghambatan fosfodiesterase sehingga kadar cAMP dalam sel beta pankreas meningkat. $\mathrm{Hal}$ ini akan merangsang sekresi insulin melalui jalur Ca (Ohno et al, 1993). Peningkatan kadar cAMP ini akan menyebabkan penutupan kanal K+ATP dalam membran plasma sel beta. Keadaan ini mengakibatkan terjadinya depolarisasi membran dan membukanya saluran Ca tergantung-voltasi sehingga mempercepat masuknya ion $\mathrm{Ca}$ ke dalam sel. Peningkatan ion Ca dalam sitoplasma sel beta ini akan menyebabkan sekresi insulin oleh sel beta pankreas (Sato et al, 1999; Yamada et al, 2002).

Selain itu Flavonoid, terutama quercetin merupakan penghambat yang kuat terhadap GLUT 2 pada mukosa usus, suatu lintasan absorbsi glukosa dan fruktosa pada membran usus. Mekanisme penghambatan ini bersifat nonkompetitif. Hal ini menyebabkan pengurangan penyerapan glukosa dan fruktosa dari usus sehingga kadar glukosa darah turun (Juan Song et al, 2002; Oran et al, 2007). Mekanisme ini mengasumsikan bahwa penghambatan GLUT 2 usus dapat menjadi terapi potensial untuk mengontrol kadar glukosa darah (Kellet and Edith, 2005).

Hasil uji tukey 1\% pada kelompok III dan IV menunjukkan notasi yang sama, hal ini disebabkan oleh perbedaan dosis yang diberikan antara kelompok III dan IV tidak jauh berbeda sehingga efek antioksidan dan penurunan kadar glukosa darah yang ditimbulkan hampir sama dan dapat diartikan tidak berbeda nyata.

\section{SIMPULAN}

Berdasarkan dari hasil penelitian yang telah dilakukan maka dapat ditarik beberapa kesimpulan yaitu pemberian ekstrak daun pletekan berpotensi sebagai protektor sel $\beta$ pankreas dan mampu menurunkan kadar glukosa darah akibat induksi radikal bebas pada tikus putih (Rattus norvegicus) strain wistar. Dosis efektif ekstrak daun pletekan adalah 0,5562 ml/ekor/hari (kelompok IV).

\section{DAFTAR PUSTAKA}

Adam, JMF, 2000, Klasifikasi dan Kriteria Diagnosis Diabetes Mellitus yang Baru, Fakultas Kedokteran Universitas Hassanudin, Ujung Pandang.

Berger, A, 1985, The Mechanism of Alloxan, New York, Delmar Publisher.

Bloom, M, 1976, Evolution in the Genus Ruellia (Acanthaceae) a Discussion Based on Floral Flavonoids, American Journal of Botany, V.63.

Chwan-fwu Lin, Yu-ling Huang, Lee-ying Cheng, Shuenn-Jyi Sheu, Chien-chih Chen, 2006, Bioactive Flavonoids From Ruellia Tuberosa, J Chin Med, Thaiwan

Dalimartha, Setiawan, 2005, Ramuan Tradisional Untuk Pengobatan Diabetes Mellitus, Jakarta, Penebar Swadaya.

Foster, DW, 2000, Diabetes Melitus. Prinsip-Prinsip Ilmu Penyakit Dalam Horrison, Jakarta, EGC.
Filipponi P, Gregorio F, Cristallini S, Ferrandina C, Nicoletti I, Santeusanio F, 2009, Selective impairment of pancreatic A cell suppreession by glucose during acute alloxan - induced insulinopenia in vitro study on isolated perfused rat pancreas, cited 2009 February 18, available from: www.ncbi.nlm.nih.gov/pubmed/3522212.

Ghoshal, M.N, 1978, Fundamental of Experimental Pharmacology, Scientific Book Agency, Calcuta.

Gustaviani, Reno, 2006, Buku Ajar Ilmu Penyakit Dalam Jilid III, Pusat Penerbitan Departemen Ilmu Penyakit Dalam Fakultas Kedokteran Universitas Indonesia, Jakarta.

Ghosh, M.N, 1971, Fundamental of Experimental Pharmacology, Scientific Book Agency, Calcuta.

Guyton, Arthur C, 2007, Textbook of Medical Physiology $11^{\text {th }}$ ed, Jakarta, EGC.

Hideaki Kaneto, Katakami Naoto, Saito Miyoko, Matsuhisa Munehide, Kawamori Ryuzo, Osonoi Takeshi, Yamasaki Yoshimitsu, 2009, Combined effect of oxidative stress-related gene polymorphisms on the progression of carotid atherosclerosis in Japanese type 2 diabetes Atherosclerosis, Diabetes Research and Clinical Practice,Volume 207, Issu1.

Karam, H.J, 1989, Pancreatic Hormone and Antidiabetic Drugs, University of California, San Fransisco.

Kellet, Edith J. M., 2005, Intake of The Plant Lignans Secoisolaricirssinol, Matairesinol, Lariciresinol, and pinoresinol in Dutch Men and Women, Centre for Nutritionand Health, National Institute for public Health and The environment,3720 BA Bithoven, Netherlands.

Kusumawati D, 2004, Bersahabat Dengan hewan Coba, Fakultas Kedokteran Hewan Universitas Airlangga, Surabaya, Gajah Mada University Press.

Lenny Sovia, Ssi, Msi, 2006, Senyawa Flavonoida, Fenilpropanoida, dan Alkaloida, Departemen Kimia Fakultas Matematika dan Ilmu Pengetahuan Alam Universitas Sumatera Utara, Medan, Unpublish..

Lenzen, S, 2008, The Mechanism of Alloxan and Streptozotoccin Induced Diabetes, Institute of Clinical Biochemistry, Hannover Medical School, Germany: http://mhhannover.de/klinische_biochemic.html.

Long, W.R, 1976, Biosystematic of Ruellia Tuberosa L. (Achantaceae) Vol.63, Am Jour of Bot.

Lovelles, A.R, 1991, Pinsip-prinsip Biologi Tumbuban Untuk Daerah Tropik, Jakarta, Gramedia.

Mulder H, Samuel GM, Christer B, Frank S, Bo A, 2005, Islet Amyloid Polypeptide (Amylin)-Deficiebt Nice Develop a More Severe Fonn of Aloxxan-Induced Diabetes. Available from: http://ajpendo.physiology.org.

Murray, R.K, Granner, D, K, mayes, P.A: Radwel., V.W., 2003. Harper Biochemistry. 25/ E, diterjemahkan : Hartono A (ed) dalam Biokimia Harper EGC, Jakarta.

Nijveldt, R.J., E. van Nood, D.E.C van Hoorn, P.G. Boelens, K. Van Norren \& P.A.M. van Leeuwen. 2001. Flavonoids: a review ofprobable mechanism of action and potential applications. Am. J. Clin. Nutr.

Nugroho B.A, Puwaningsih , 2002, Pengaruh diet ekstrak rumput laut (Eucheuma sp.) terhadap kadar glukosa darah tikus putih ( Rattus norvegicus ) biperglikemik, Media Medika Indonesia Vol.39.

Ohno T, 1993, Quercetin potentiates TNF-induced antiviral activity. Antiviral Res. 
Oran et al, 2007, Flavonoid Inbibition of Sodium-dependent Vitamin C Transporter 1 (SVCT1) and Glucose Transporter Isoform 2 (GLUT2), Intestinal Transporters for Vitamin C and Glucose. JBC, The Journal of Biologycal Chemistry, USA.

Rho, Hye-won, Ji-Nalee, Ki rho hyung, Park Byung-Hyun and Park Jin-Woo, 2000, Proactive Mechanism of Glucose Against Alloxan Induced â-cell Damage: Pivotal Role of ATP, Korea Eksperimental and Molecular Medicine Vol 23.

Sacks, D.B., 2001, Carbobydrates in Tietz. Fundamentalis of Clinical Chemistry Eds Burtis C. A. A. Swood e. R., $5^{\text {th }}$ Edition, W, B. Saunders Company, USA.

Sato et al, 1999, Mechanism of antioxidant action of pueraria glycoside (PG)-l (an isoflavonoid) and maniferin (a xanthonoid). Chem Pharm Bull 40.

Schteingart, David E, 2005, Konsep Klinis Proses-Proses Penyakit; Metabolisme Glukosa dan Diabetes Melitus, Jakarta, EGC, Absolut;2004.

Solikin, 2007, Potensi Jenis-jenis Herba Liar di Kebun Raya Purwodadi Sebagai Obat, UPT. Balai Konservasi Tumbuhan Kebun Raya Purwodadi, LIPI.

Song, Juan et al, 2002, Flavonoid Inbibition of Sodium-dependent Vitamin C Transporter 1 (SVCT1) and Glucose Transporter Isoform 2 (GLUT2), Intestinal Transporters for Vitamin C and Glucose. JBC, The Journal of Biologycal Chemistry, USA.

Studiawan, H dan santosa MH, 2005, Uji Aktivitas Penurun Kadara Glukosa Darah Ekstrak Daun Eugenia polyantha pada Tikus yang Diinduksi Alloxan Dengan Metode Aloksan. Jurnal Penelitian Medika Eksakta Vol.5 No3, Surabaya, Bagian Ilmu Bahan Alam, Fakultas Farmasi Universitas Airlangga.

Subroto, Ahkam, 2006. Ramuan Herbal Untuk Diabetes Mellitus. Penebar Swadaya, Jakarta.

Sudjari, 2006, Tikus Wistar Sebagai Hewan Coba Untuk Penelitian Dengan Toksoid Tetanus, Malang, Majalah Kedokteran UNIBRAW Vol: XII No.3.

Suhartono dkk,2004, Kaktus Manis Si Obat Kolesterol. http: / / www.indosiar.com / v2 / culture / pentas_arsip.htm. diakses 13 Oktober 2010.

Watkins D, Cooperstein SJ, Lazarow A, 2008, Effect of alloxan on permeability of pancreatic islet tissue in vitro. [cited 2009 February 18]. Available from: http:/ ajplegacy. physiology.org/cgi/content/abstract/207/2/ 436.

Yamada, 2002, In vivo Anti-influenza Virus Activity of Plant Flavonoids Possessing Inbibitory Activity for Iinfluenza Virus Sialidase. Antiviral Res 19. 